\title{
Antimicrobial and cytotoxic activity of Alnus glutinosa (L.) Gaertn., A. incana (L.) Moench, and A. viridis (Chaix) DC. extracts
}

Sabina Dahija1*, Sanin Haverić², Jasmina Čakar², Adisa Parić1

'Department of Biology, Faculty of Science, University of Sarajevo, Sarajevo, Bosnia and Herzegovina, ${ }^{2}$ Institute for Genetic Engineering and Biotechnology, Sarajevo, Bosnia and Herzegovina

\begin{abstract}
Introduction: The objective of the present study was to evaluate the antimicrobial and cytotoxic activities of water extracts of leaves and barks from Alnus glutinosa (L.) Gaertn., A. incana (L.) Moench, and A. viridis (Chaix) DC.
\end{abstract}

Methods: The antimicrobial activities of extracts were tested against gram-negative and gram-positive bacteria as well as yeast strains by the agar diffusion method. The cell viability was determined by the Trypan blue dye exclusion method.

Results: The largest diameters of inhibition zone (DIZ) were recorded with Staphylococcus aureus ATCC 6538 and Bacillus subtilis 168M. The highest percentage of cell viability was observed with water bark extracts of A. glutinosa (97.46\%).

Conclusions: Potential antimicrobial properties of $A$. glutinosa, $A$. incana, and $A$. viridis demonstrated in this study, as well as their low levels of toxicity, make them an interesting subject for further studies.

Keywords: Antibacterial activity; antifungal activity; cytotoxic activity; Alnus

\section{INTRODUCTION}

Plants have been used as natural sources of medicinal agents from the beginning of human civilization. Interest for plants with potential medicinal usage has increased in recent years because of their effects, including antioxidant, antiviral, antibacterial, and anticancer activity. According to the

\footnotetext{
*Corresponding author: Sabina Dahija, Department of Biology, Faculty of Science, University of Sarajevo, Zmaja od Bosne 33-35, 71000 Sarajevo, Bosnia and Herzegovina, Tel.: +387 33723702 .

E-mail: sabina_dudevic@yahoo.com
}

Submitted: 4 February 2016/Accepted: 4 June 2016

DOI: http://dx.doi.org/10.17532/jhsci.2016.328
World Health Organization, nearly 50,000 people die each day throughout the world from infectious diseases (1). Recently, the effectiveness of many synthetic antibiotics has become a serious problem because of the emergence of resistance (2). Therefore, the plants are becoming more interesting as a potential source of new antimicrobial agents.

According to Mitchell and Wilkinson (3) and O'Rourke et al. (4), the Alnus genus (Betulaceae) include about 30 species of trees and shrubs found in the Northern Hemisphere $(3,4)$. This genus is represented in Bosnia and Herzegovina by three species: Alnus glutinosa (L.) Gaertn. (black alder), 
A. incana (L.) Moench (gray alder), and $A$. viridis (Chaix) DC. (green alder).

The plants of this genus have been found active against hepatitis, HIV-1 viral replication, and cancer (5-7) due to the presence of plant secondary metabolites, including terpenoids (e.g. secodammarane-type triterpenoids), flavonoids, diarylheptanoids, phenols, steroids, and tannins $(8,5)$. Traditionally, extracts of Alnus species are used for gastrointestinal, skin diseases, and bacterial infections of the mouth and throat (9-12). Extracts of some Alnus species have immunostimulatory properties and are used in anticancer therapy (13-15). There are no published data on antimicrobial or cytotoxic activity of three Alnus species that naturally grow in Bosnia and Herzegovina. Therefore the aim of our study was to examine possible antimicrobial and cytotoxic activity of the water extracts of three Alnus species.

\section{METHODS}

\section{Plant material}

The plant material (leaves and bark) of $A$. glutinosa, $A$. incana, and $A$. viridis was collected in June 2009 on the mountain Vranica in Central Bosnia. A voucher specimen is deposited in the Herbarium of the National Museum of Bosnia and Herzegovina.

Leaves and bark of the three Alnus species were dried in the shade at room temperature in airy place. Twenty grams of the chopped, dried leaves and of bark were extracted with water by a Soxhlet apparatus. All extracts were kept at $+4^{\circ} \mathrm{C}$ for up to 1 week until antimicrobial and cytotoxicity tests were carried out.

\section{Antibacterial and antifungal assays}

Antibacterial activity of the plant extracts was determined by the disc diffusion method (16). Three gram-positive bacteria (Bacillus subtilis 168M, Staphylococcus aureus ATCC 6538, Micrococcus luteus DSM 1790), three gram-negative bacteria (Escherichia coli K12 strain DH5alpha (BRL), Pseudomonas aeruginosa ATCC 27853, Salmonella abony NCTC 6017) and two yeast strains (Candida albicans ATCC 10231 and Aspergillus brasiliensis ATCC 16404) were used for the present study. The bacterial strains were grown in Mueller Hinton Agar (Himedia, Mumbai, India) and the yeast strains were grown in Sabouraud Dextrose Agar (Himedia, Mumbai, India). Dried filter paper discs $(5 \mathrm{~mm}$ in diameter) impregnated with $30 \mu \mathrm{l}$ of the extracts and placed on the agar plates were uniformly seeded with the test organisms. The treated Petri dishes were left at room temperature for 10 minutes and then incubated at $37^{\circ} \pm 0.1^{\circ} \mathrm{C}$ for 24 hours for bacteria and 48 hours for fungi. At the end of the incubation period, inhibition zones of the extracts formed on the medium were measured and expressed in millimeters. Chloramphenicol (Caelo, Caesar \& Loretz, Hilden, Germany) and Kanamycin (Duchefa, Haarlem, The Netherlands) in concentrations of $5 \mathrm{mg} / \mathrm{ml}$, and $2 \mathrm{mg} / \mathrm{ml}$ of Nystatin (Caelo, Caesar \& Loretz, Hilden, Germany), were used as positive reference standards to determinate the sensitivity of each of the tested microorganism strains. A negative control was sterile distilled water.

\section{Cytotoxic assay}

Cytotoxic activity of the water extracts of three Alnus species was analyzed by the Trypan Blue dye exclusion method adopted by Freshney (17). The human fibroblast cells were seeded at a density of $1 \times 10^{5}$ cells/well. These cell lines were cultured in RPMI-1640 medium. The media were supplemented with fetal bovine serum, glutamine, penicillin, and streptomycin. The cells were plated onto 96-well plates and allowed to grow in $\mathrm{CO}_{2}$ incubator for 24 hours $\left(37^{\circ} \mathrm{C}, 5 \% \mathrm{CO}_{2}\right)$. After 24 hours, the cells were treated with the plant extracts to final concentrations of 15 and $30 \mu \mathrm{l} / \mathrm{ml}$. Culture medium was used instead of the plant extract for the negative control. At the end of 72 hours incubation, $20 \mu \mathrm{l}$ of medium and equal volume of $0.4 \%$ trypan blue were added and cell viability was determined using hemocytometer. Cells were examined and counted in duplicates under a light microscope at 100x (Olympus, Japan). When observed under the microscope, non-viable cells are stained blue while viable cells remain unstained (18).

\section{Statistical analysis}

All experiments were carried out independently three times. Results are presented as mean \pm standard deviation. 


\section{RESULTS}

In our study, antimicrobial activity of water extracts obtained from the leaves and bark of $A$. glutinosa, $A$. incana, and $A$. viridis were tested against eight microorganisms (Table 1). The data indicated that the gram-positive $S$. aureus strain was the most sensitive to the water extracts of $A$. viridis (21.3 \pm $1.15)$ and $A$. glutinosa $(19.3 \pm 1.15)$ leaves. All tested extracts (except $A$. glutinosa bark) showed inhibitory effect on the E. coli strain. It is important to mention the results on $P$. aeruginosa strain which is known to be very resistant (Table 1 ).

The water extract from $A$. viridis leaves and bark was the most active extract, and this result was comparable to the results obtained with the standards, Chloramphenicol $(5 \mathrm{mg} / \mathrm{ml})$ and Kanamycin $(5 \mathrm{mg} / \mathrm{ml})$. The tested extracts showed no inhibitory activity on the $C$. albicans, $A$. brasiliensis, and S. abony strains.

The results of the cytotoxicity test on the human fibroblast cells are shown in Table 2. The highest percentage of cell viability was observed using the water extracts of A. glutinosa bark (97.46\%). The cell viability results demonstrate that two concentrations of plant extracts values were higher than $85 \%$, which is similar to that of control. The Trypan blue test showed that the water extracts at concentrations of 15 and $30 \mu \mathrm{l} / \mathrm{ml}$, obtained from leaves and bark of the three Alnus species, had no toxicity effects on the human fibroblast cells.

\section{DISCUSSION}

Numerous species of Alnus have been used as traditional herbal medicines since many components from this genus have showed significant bioactivities. Our previous results suggest that $A$. glutinosa, $A$. incana, and $A$. viridis have strong antimicrobial and antioxidant potential due to the presence of large quantities of phenols and flavonoids (12). In this study, the antimicrobial activity test showed that the leaf and bark extracts of $A$. viridis inhibited the growth of almost all the microorganisms, except S. abony, C. albicans, and $A$. brasiliensis. Stević et al. (11) showed that $A$. incana and $A$. viridis bark, cone, and leaf extracts inhibited $S$. aureus growth and had a synergistic effect against bacteria resistant to the known antibiotics. Middleton et al. (19) also reported antimicrobial activity of $A$. glutinosa against eight bacterial species and confirmed the usage of this species in traditional medicine. These results are consistent with previous reports on related plants regarding antibacterial activity (12). Earlier, it was noted that differences in the antibacterial activity are associated with secondary metabolites (tannin and phenol) $(12,20)$.

According to our results, the leaf and bark extracts showed no toxicity within the concentrations tested on the human fibroblast cell cultures. This is the first study that evaluated the cytotoxic activities of Alnus species from Bosnia and Herzegovina, which is considered as a member of plant family reported

TABLE 1. Antibacterial and antifungal activity of three Alnus species

\begin{tabular}{|c|c|c|c|c|c|c|}
\hline \multirow[t]{3}{*}{ Microorganism } & \multicolumn{6}{|c|}{ Zone of inhibition (mm) } \\
\hline & \multicolumn{2}{|c|}{ Alnus glutinosa } & \multicolumn{2}{|c|}{ Alnus incana } & \multicolumn{2}{|c|}{ Alnus viridis } \\
\hline & Leaves & Bark & Leaves & Bark & Leaves & Bark \\
\hline Bacillus subtilis & - & - & - & $17.6 \pm 0.57^{b}$ & - & $21 \pm 1.73^{a}$ \\
\hline Staphylococcus aureus & $19.3 \pm 1.15$ & - & - & - & $21.3 \pm 1.15^{\mathrm{a}}$ & - \\
\hline Micrococcus luteus & - & - & - & - & - & $15.3 \pm 5.03$ \\
\hline Escherichia coli & $15 \pm 6.24$ & - & $13.6 \pm 2.3$ & $10.6 \pm 0.57^{b}$ & $18 \pm 8$ & $18 \pm 6.53$ \\
\hline Pseudomonas aeruginosa & - & $11.3 \pm 6.24^{b}$ & - & - & $19.6 \pm 6.35$ & - \\
\hline Salmonella abony & - & - & - & - & - & - \\
\hline Candida albicans & - & - & - & - & - & - \\
\hline Aspergillus brasiliensis & - & - & - & - & - & - \\
\hline
\end{tabular}

- No inhibition zone, ${ }^{\text {E} E x t r a c t ~ w i t h ~ s t r o n g e r ~ e f f e c t ~ t h a n ~ C h l o r a m p h e n i c o l, ~}{ }^{b}$ Extract with lower effect than Kanamycin, Kanamycin (22 \pm 2.64$)$,

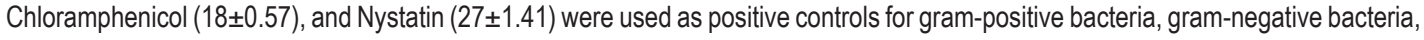
and yeast, Negative control was sterile distilled water 
TABLE 2. Cytotoxic activity of three Alnus species

\begin{tabular}{|c|c|c|}
\hline \multirow[t]{2}{*}{ Sample } & \multicolumn{2}{|c|}{$\begin{array}{c}\text { Percentage of } \\
\text { viability }(\%)\end{array}$} \\
\hline & $15 \mu \mathrm{l} / \mathrm{ml}$ & $30 \mu \mathrm{l} / \mathrm{ml}$ \\
\hline Alnus glutinosa-leaves & 94.50 & 93.50 \\
\hline Alnus glutinosa-bark & 97.46 & 91.23 \\
\hline Alnus incana-leaves & 88.23 & 93.47 \\
\hline Alnus incana-bark & 90 & 85.52 \\
\hline Alnus viridis-leaves & 89.83 & 96.92 \\
\hline Alnus viridis-bark & 89.28 & 93.30 \\
\hline Control & 94.92 & \\
\hline
\end{tabular}

${ }^{*}$ Culture medium was used instead of the plant extract for the negative control

to demonstrate interesting biological activities. Middleton et al. (19) evaluated A. glutinosa extracts, obtained with different solvents, for toxicity using the brine shrimp lethality assay. All three extracts of $A$. glutinosa showed low levels of toxicity toward brine shrimps $\left(\mathrm{LD}_{50}\right.$ values were in the range of 1.29 $\times 10^{-1}$ to $\left.8.30 \times 10^{-1} \mathrm{mg} / \mathrm{ml}\right)(19)$.

The development of new studies using other methods for plant extraction is suggested as well as the use of extracts obtained in the presence of other solvents but always coupled with toxicity tests.

\section{CONCLUSION}

No data have been published on antimicrobial or cytotoxic activity for three examined Alnus species in Bosnia and Herzegovina. It is evident from this study that water extracts from leaves and bark of the three Alnus species exhibited moderate to good antibacterial activity against the tested organisms.

\section{CONFLICT OF INTEREST}

The authors declare no conflict of interest.

\section{ACKNOWLEDGMENTS}

The authors wish to acknowledge the financial support of Canton Sarajevo Ministry of Education and Science (Grant No. 11-14-19953.1/07) for funding the research. The authors are thankful to assistant professor Neđad Bašić for plant determination and Dr. Erna Karalija, for assistance in our work.

\section{REFERENCES}

1. Rakholiya K, Chanda S. In vitro interaction of certain antimicrobial agents in combination with plant extracts against some pathogenic bacterial strains. Asian Pac J Trop Biomed. 2012;2(2):S876-80.

http://dx.doi.org/10.1016/S2221-1691(12)60327-X.

2. Eldeen IM, Elgorashi EE, van Staden JV. Antibacterial, anti-inflammatory, anti-cholinesterase and mutagenic effects of extracts obtained from some trees used in South African traditional medicine. J Ethnopharmacol. 2005;102(3):457-64.

http://dx.doi.org/10.1016/j.jep.2005.08.049.

3. Mitchell A, Wilkinson J. Parey's Buch der Baume (The trees of Britain and Northern Europe, 1982). $3^{\text {rd }}$ ed. Berlin, Germany: Blackwell WissenschaftsVerlag; 1997

http://dx.doi.org/10: 0002190354.

4. O'Rourke C, Byres M, Delazar A, Kumarasamy Y, Nahar L, Stewart F, et al. Hirsutanonol, oregonin and genkwanin from the seeds of Alnus glutinosa (Betulaceae). Biochem System Ecol. 2005;33:749-52.

http://dx.doi.org/10.1016/j.bse.2004.10.005.

5. Sati SC, Sati N, Sati OP. Bioactive constituents and medicinal importance of genus Alnus. Pharmacogn Rev. 2011;5(10):174-83.

http://dx.doi.org/10.4103/0973-7847.91115.

6. Yu YB, Miyashiro H, Nakamura N, Hattori M, Park JC. Effects of triterpenoids and flavonoids isolated from Alnus firma on HIV-1 viral enzymes. Arch Pharm Res. 2007; 30(7):820-6. http://dx.doi.org/10.1007/ BF02978831.

7. Choi SE, Kim KH, Kwon JH, Kim SB, Kim HW, Lee MW. Cytotoxic activities of diarylheptanoids from Alnus japonica. Arch Pharm Res. 2008;31(10):1287-9.

http://dx.doi.org/10.1007/s12272-001-2108.

8. Ludwiczuk A, Saha A, Kuzuhara T, Asakawa Y. Bioactivity guided isolation of anticancer constituents from leaves of Alnus sieboldiana (Betulaceae). Phytomedicine. 2011;18(6):491-8.

http://dx.doi.org/10.1016/j.phymed.2010.10.005.

9. Ritch-Krc EM, Turner NJ, Towers GHN. Carrier herbal medicine: An evaluation of the antimicrobial and anticancer activity in some frequently used remedies. J Ethnopharmacol. 1996;52(3):151-6. http://dx.doi.org/10.1016/0378-8741(96)01407-9.

10. Saxena G, Farmer S, Hancok RE, Towers GH. Antimicrobial compounds from Alnus rubra. Int J Pharmacogn. 1995;33(1):33-6. http://dx.doi.org/10.3109/13880209509088144.

11. Stević T, Šavikin K, Zdunić G, Stanojković T, Juranić Z, Janković T, et al. Antioxidant, cytotoxic and antimicrobial activity of Alnus incana (L.) ssp. incana Moench and A. viridis (Chaix) DC ssp. viridis extracts. J Med Food. 2010;13(3):700-4. http://dx.doi.org/10.1089/jmf.2009.0111.

12. Dahija S, Čakar J, Vidic D, Maksimović M, Parić A. Total phenolic and flavonoid contents, antioxidant and antimicrobial activities of Alnus glutinosa (L.) Gaertn., Alnus incana (L.) Moench and Alnus viridis (Chaix) DC. extracts. Nat Prod Res. 2014;28(24):2317-20. http://dx.doi.org/10.1080/14786419.2014.931390.

13. Sheth K, Bianchi E, Wiedenhopf R, Cole JR. Antitumor agents from Alnus oregana (Betulaceae). J Pharm Sci. 1973;62(1):139-40. http://dx.doi.org/10.1002/jps.2600620129.

14. Joo SS, Kim MS, Oh WS, Lee DI. Enhancement of NK cytotoxicity, antimetastasis and elongation effect of survival time in B16-F10 melanoma cells by oregonin. Arch Pharm Res. 2002;25(4):493-9.

http://dx.doi.org/10.1007/BF02976608. 
15. Park D, Kim HJ, Jung SY, Yook CS, Jin C, Lee YS. A new diarylheptanoid glycoside from the stem bark of Alnus hirsuta and protective effects of diarylheptanoid derivatives in human HepG2 cells. Chem Pharm Bull (Tokyo). 2010;58(2):238-41.

http://doi.org/10.1248/cpb.58.238.

16. Nikšić H, Kovač-Bešović E, Makarević E, Durić K. Chemical composition, antimicrobial and antioxidant properties of Mentha longifolia (L.) Huds. essential oil. Journal of Health Sciences 2010;2(3):192-200.

http://dx.doi.org/10.17532/jhsci.2012.38.

17. Freshney RI. Culture of animal cells: A manual of basic technique. $5^{\text {th }}$ ed. Hoboken NJ: John Wiley \& Sons; 2005.

http://dx.doi.org/10.1002/0471747599.cac034.

18. Ramamurthy SK, Pittu VP, Kotturi R, Devi P, Kumar S. In vitro cytotoxic activity of methanol and acetone extracts of Parthenium hysterophorus flower on A549 cell lines. Int J Pharm Sci Review and Research. 2011;10(2):95-9.

19. Middleton P, Stewart F, Al-Qahtani S, Egan P, O'Rourke C, Abdulrahmanm A, et al. Antioxidant, antibacterial activities and general toxicity of Alnus glutinosa, Fraxinus excelsior and Papaver rhoeas. Iranian J Pharm Sci. 2005;4(2):81-6.

http://dx.doi.org/10.1007/s11273-003-5024-9.

20. Akinyemi KO, Oladapo O, Okwara CE, Ibe CC, Fasure KA. Screening of crude extracts of six medicinal plants used in southwest Nigerian unorthodox medicine for antimethicillin resistant Staphylococcus aureus activity. BMC Complement and Altern Med. 2005;5:6.

http://dx doi.org/10.1186/1472-6882-5-6. 